\title{
Plant diversity along a disturbance gradient in a semi-arid ecosystem in Central Mexico
}

\section{Diversidad vegetal a lo largo de un gradiente de perturbación en un ecosistema semi-árido en el Centro de México}

\author{
Osvaldo Eric Ramírez-Bravo1,2,4 and Lorna Hernández-Santin³
}

1 University of Kent, Durrell Institute for Conservation Ecology, Marlowe Building, CT2 7NR, Canterbury, Kent, England.

2 Current address: Benemérita Universidad Autónoma de Puebla, Instituto de Ciencias, Departamento Universitario para el Desarrollo Sustentable, 14 Sur 6301, CoIonia San Manuel, Ciudad Universitaria, 72570 Puebla, Puebla, México.

3 University of Queensland, School of Biological Sciences, Brisbane St Lucia, QLD 4072 Queensland, Australia.

4 Author for correspondence: ermexO2@yahoo.com

\section{To cite as}

Ramírez-Bravo, O. E. y L. Hernández-Santin. 2016. Plant diversity along disturbance gradient in a semi-arid ecosystem in Central Mexico. Acta Botanica Mexicana 117: 11-25.

Received: 28 de agosto de 2013 Reviewed: 29 de noviembre de 2013. Accepted: 12 de julio de 2016.

\begin{abstract}
:
Background and Aims: Habitat fragmentation and other human disturbances can cause loss of soil fertility, erosion, biodiversity, among others; however, available information in arid regions is limited. Our aim was to determine the effects of a disturbance gradient on species composition in two vegetation types in a semi-arid area of central Mexico.

Methods: We selected six patches, three of shrubland and three of tropical dry forest, in the area of Cerro Colorado. We quantified the species and generic diversity of ten quadrats per patch (60 in total), placed randomly, during the months May-June 2011. We developed a disturbance index based on disturbances such as grazing and wood use among others. High, medium and low disturbance areas were identified in both tropical dry forest and shrubland.

Key results: Results indicate that tropical dry forest is more diverse than shrubland. The shrubs Cnidoscolus tehuacanensis and Mimosa luisana were indicators of disturbance as they are found in higher relative abundance in highly disturbed quadrats. In tropical dry forest, three genera (Thevetia, Acacia and Bursera) showed higher relative abundance in conserved patches while in shrubland only one (Parkinsonia) shows this pattern, hence they could serve as indicator species.

Conclusions: Our results provide evidence that disturbance in semi-arid areas of central Mexico plays an important role in species composition, facilitating the establishment of certain native species that can be considered colonizer species. These native species could be used as indicators of disturbance in assessing habitat suitability for different species.
\end{abstract}

Key words: arid zones, conservation, Tehuacán-Cuicatlán Valley.

\section{Resumen:}

Antecedentes y Objetivos: La fragmentación del hábitat y otras alteraciones humanas pueden causar la pérdida de fertilidad del suelo, erosión y la pérdida de biodiversidad, entre otras; sin embargo, la información en zonas áridas es limitada. El objetivo de este trabajo fue determinar los efectos de un gradiente de disturbio en la composición de especies en dos tipos de vegetación en un ecosistema semi-árido del centro de México.

Métodos: Se seleccionaron seis zonas de estudio diferentes en la zona de Cerro Colorado, tres de matorral xerófilo y tres de bosque tropical caducifolio. Se determinó la diversidad genérica y específica utilizando 10 cuadrantes (un total de 60), localizados al azar, durante los meses de mayo-junio de 2011. Se generó un índice de perturbación basado en las actividades que se registraron en la región como pastoreo y tala, entre otros. Las áreas de alto, medio y bajo disturbio se identificaron en el matorral xerófilo y bosque tropical caducifolio.

Resultados clave: Los resultados mostraron que el bosque tropical caducifolio es más diverso que el matorral xerófilo, además de que es posible utilizar a los arbustos Cnidoscolus tehuacanensis y Mimosa luisana como indicadores, ya que se encontraban en lugares con altos niveles de perturbación. Por otro lado, en el bosque tropical caducifolio, tres géneros (Thevetia, Acacia y Bursera) presentan altas abundancias relativas en lugares conservados, mientras que en el matorral xerófilo solo uno (Parkinsonia) tiene este patrón.

Conclusiones: De los resultados se puede inferir que en hábitats semiáridos del Centro de México las actividades antropogénicas juegan un papel importante en la diversidad florística, ya que facilitan el establecimiento de algunas plantas nativas que pueden ser consideradas como colonizadoras. Estas pueden ser utilizadas como indicadoras de los disturbios con la finalidad de determinar la viabilidad de hábitat para otros taxa.

Palabras clave: conservación, Valle de Tehuacán-Cuicatlán, zonas áridas. 


\section{INTRODUCTION}

Areas with high vegetative diversity tend to be threatened by habitat fragmentation and other human disturbances (Myers, 1988). This is serious because fragmentation diminishes biodiversity (Collinge et al., 2003), given that species composition on a patch will depend on its size and isolation (Crooks, 2002). Some of the negative effects of disturbances that have been reported are the following: soil fertility loss and erosion (Wezel and Rath, 2002), less vegetative (Nikiema, 2005) and fauna diversity (Blaum et al., 2007), favoring the establishment of invasive species (McDougall and Turkington, 2005) and brush encroachment (Van Auken, 2000), amongst others.

In central Mexico, the information about such effects in arid regions is limited to records of specific impacts in small areas (e.g. Giordani, 2008; Parra et al., 2008). This kind of information is necessary in the semi-arid area of Cerro Colorado that, being adjacent to the Tehuacán-Cuicatlán Biosphere Reserve, can be considered as highly biodiverse (Fig. 1). The region is highly heterogeneous, with more than 26 vegetation assemblages that can be grouped in tropical shrubland, as well as oak and pine forest (Valiente-Banuet et al., 2000). This area is important to conservation given its potential to serve as corridor for many species (Ramírez-Bravo, 2010). However, it is exposed to strong human pressure, with activities such as livestock grazing (Giordani, 2008), wood cutting (Pérez-Negrón and Casas, 2007), and extraction of non-timber products such as fruits (González-Soberanes and Casas, 2004; Pérez-Negrón and Casas, 2007; Parra et al., 2008). Although these activities have been considered to have low environmental impact, Pérez-Negrón and Casas (2007) suggested that, in some communities, cactus fruit collection can total $151 \mathrm{~kg} /$ year and wood extraction for fuel can be more than 400 tons/year. Therefore, these activities have the potential to shift species diversity and composition resulting in direct species loss (Osem et al., 2002) or favoring the establishment of invasive species, either exotic or native (Valéry et al., 2004; Blaum et al., 2007) that could be used as indicator species.

The main goal of this study was to develop a simple disturbance index that could be used in the area, as well

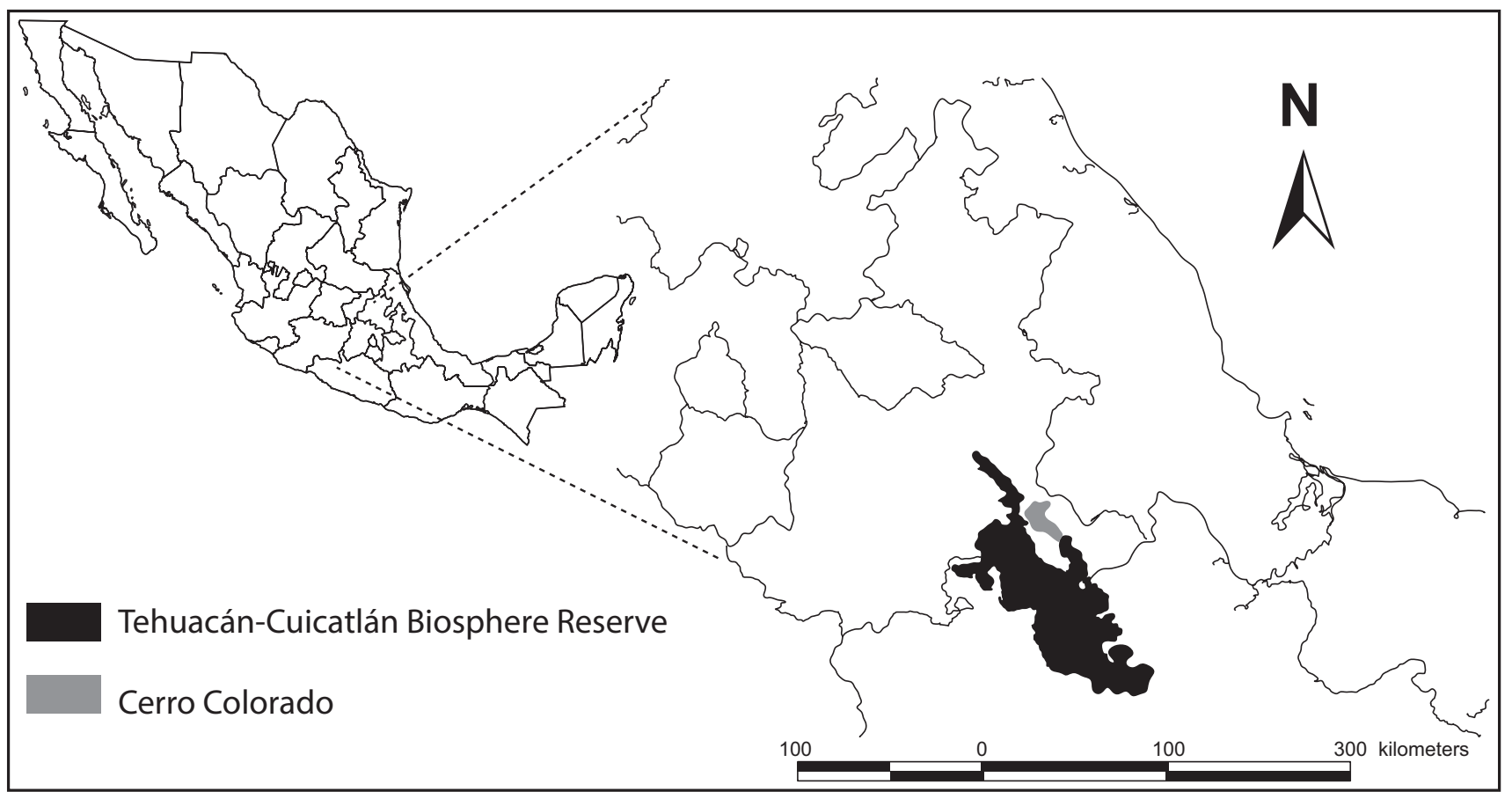

Figure 1: Map of the study area, showing the Tehuacán-Cuicatlán Biosphere Reserve and Cerro Colorado. 
as to determine the existence of indicator species that will allow quick conservation assessments. For this, we used species that have been recorded as indicators of human disturbances and that are known to encroach upon arid areas such as Acacias (Blaum et al., 2007) and Mimosas (Legesse, 2010).

\section{MATERIAL AND METHODS}

\section{Study area}

In southeast Puebla, located in central Mexico, our study area known as Cerro Colorado is adjacent to the Biosphere Reserve "Tehuacán-Cuicatlán" (Fig. 1). It has an area of $224.25 \mathrm{~km}^{2}$, with a centroid in the coordinates $18^{\circ} 27^{\prime} 54^{\prime \prime} \mathrm{N}, 97^{\circ} 18^{\prime} 58^{\prime \prime} \mathrm{W}$. It has different mountain ranges, with elevations between 600 and $2950 \mathrm{~m}$ asl that allow great habitat diversity. Despite the variety of vegetation association in the region, the National Forestry Inventory (SEMARNAP, 2001) identifies three main habitat types, which include tropical dry forest, shrubland, and oak and pine forest. Very distinct from its dry season, its wet season occurs from May to October and has an average precipitation of 250 to $500 \mathrm{~mm}$. Its temperature ranges between 18 and $22{ }^{\circ} \mathrm{C}$ (Botello et al., 2006).

We selected six study sites using a modified methodology based on Taki et al. (2007), where a hexagon is drawn in the center of a patch with the same vegetation type within the heterogeneous matrix using the vegetation map available from the National Commission for Knowledge and Use of Biodiversity (CONABIO). Each patch covered an area of $103923 \mathrm{~m}^{2}$ and the minimum distance left between study sites was $2.5 \mathrm{~km}^{2}$. We coded each site according to nearby populations: three representing tropical dry forest (CM: Corral Macho, SB: San Esteban and SAC: San Antonio Cañada), and three from xeric shrubland patches (SD: San Diego, AJ: Ajalpan and VA: Colonia del Valle). Due to its restricted distribution in Cerro Colorado (less than 10\%) (Bolaños-Bautista, 2011), as well as security problems by delinquent groups in these areas, oak and pine forest patches were not considered.

\section{Data collection}

\section{Disturbance}

We determined which activities were undertaken in Cerro Colorado based on bibliographical review, informal interviews with people in nearby areas and observation of activities during fieldwork. We evaluated disturbance considering ten different activities, which have been reported to be affecting natural resources in the area (Table 1). Following Espinosa et al. (2011), we visually evaluated each variable and gave it a value between zero and three depending on the activity intensity in each patch (Table 2). Disturbance values were obtained through the addition of the ten variables without giving difference to the impact of each variable (e.g. fruit collection vs. hunting), because the aim of the index is to be as simple as possible to be used by local communities for quick assessments. In or-

Table 1: Principal disturbances and their examples in the Tehuacán-Cuicatlán Valley.

\begin{tabular}{|c|c|c|c|}
\hline Effect & Place & Impact & Reference \\
\hline Livestock grazing & Zapotitlán Salinas & Seed dispersal and overgrazing & Giordani, 2008 \\
\hline Wood Cutting & Santiago Quiotepec & 464 tons of wood for fuel & Pérez-Negrón and Casas, 2007 \\
\hline $\begin{array}{l}\text { Extraction of non-timber } \\
\text { products }\end{array}$ & Santiago Quiotepec & $550 \mathrm{~kg}$ of cactus fruits & Pérez-Negrón and Casas, 2007 \\
\hline
\end{tabular}


Table 2: Activities used to obtain the disturbance index and categorization of each value.

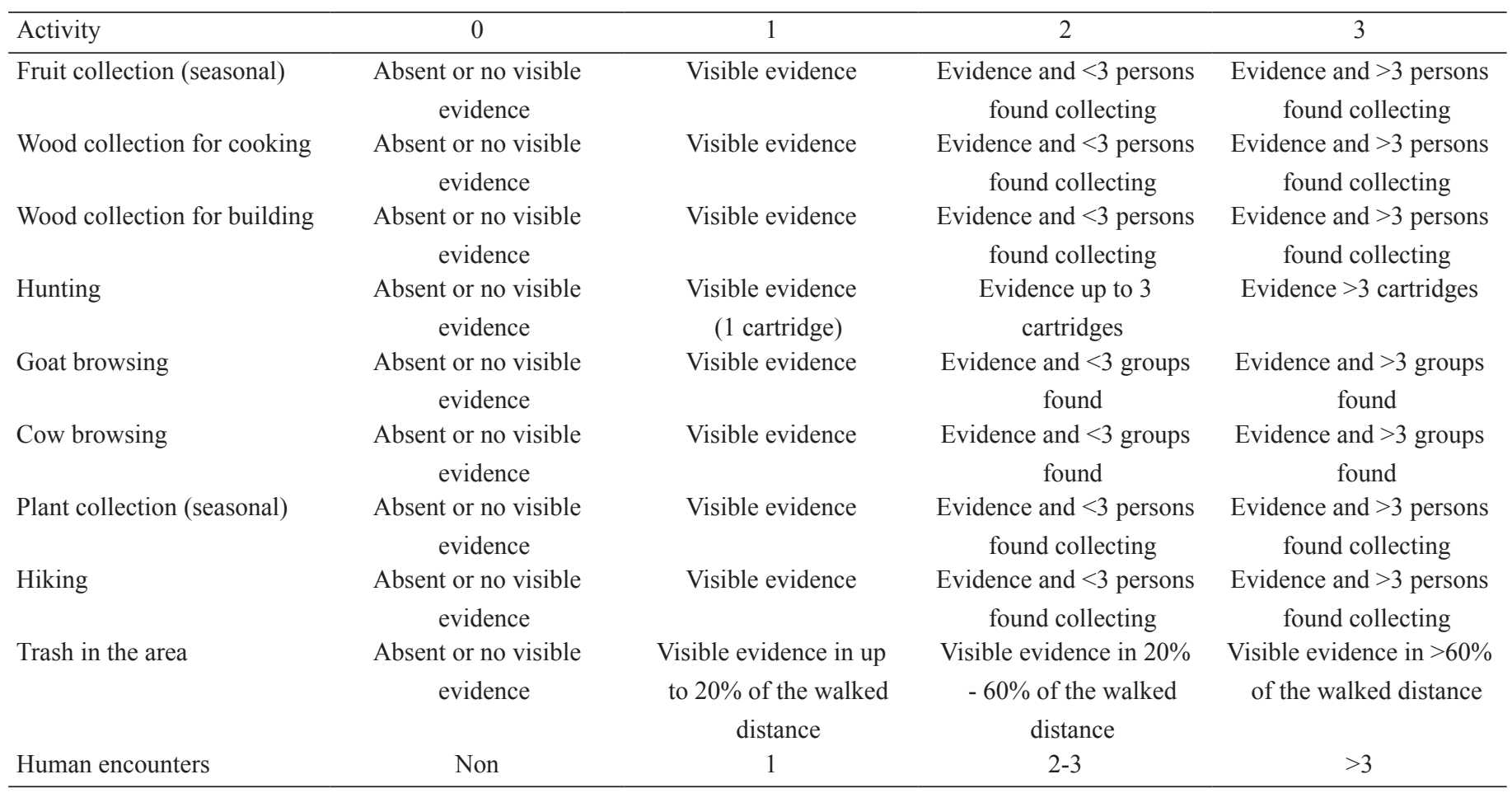

der to differentiate between conserved and disturbed environments, we divided the maximum score of 30 in three categories: low disturbance, when it had values ranging between zero and ten; medium disturbance, with values between 11 and 20; and high disturbance, with scores between 21 and 30 .

\section{Vegetation characterization}

We conducted fieldwork during May-June 2011, as trees and shrubs are easier to count during this period. We characterized vegetation in 10 quadrats of $100 \mathrm{~m}^{2}$ in each of the six previously selected study sites by using a grid over the hexagon. This area covers $10 \%$ of each vegetation patch, which is considered as the minimum recommended area to determine species presence (Sánchez-Lalinde and Pérez-Torres, 2008). Vegetation characterization was based on trees and shrubs due to their relation with other species distribution such as carnivores (Palomares, 2001), and because they represent the principal vegetation component in this kind of habitat (Valiente-Banuet et al.,
2000). We identified to genera and if possible to species level using specialized guides for the area (Guízar Nolazco and Sánchez Velez, 1991; Águilar and García, 2004; Téllez Valdés et al., 2008; Huerta Zamacona et al., 2009).

\section{Data analysis}

To determine if the sampling effort was sufficient, we generated an accumulation curve using tree and shrub species from the different study sites using the statistical software EstimateS (Colwell, 2006). Next, all data was grouped to determine the sampling effort (number of quadrats) per vegetation type (i.e. shrubland and tropical dry forest), per disturbance level (i.e. high, medium, and low), and for the study area (i.e. Cerro Colorado). We calculated species richness or the number of species present in an area; its evenness, which indicates how equal a community is; as well as its Shannon diversity index, which considers the number of species and how evenly they are distributed (Moreno, 2001). These indices were determined using Diversity add-inn (SSC, 2012) for Excel, and 
compared using an ANOVA between the different patches using Statistica (Statistica, 1999).

As in some cases identification was not possible to species level, we decided to use genera for further analysis except for Compositae and two shrub species that could not be identified and were grouped as Compositae and shrubs respectively. To determine similarities in species composition we used a nonparametric analysis of similarities test (ANOSIM) using the VEGAN software package, version 2.0-2 (Oksanen et al., 2011). This is a randomization-based analysis analogous to ANOVA, which builds a resemblance matrix that compares the species compositions of the sample groups of high and low disturbance (Ross, 2011). Results are indicated by R, which takes values between -1 and 1 , where -1 indicates a random grouping while 1 indicates highest similarity. $\mathrm{R}$ is significant when its values are significantly different from zero. To find potential indicator species of low and high disturbance, we analyzed the similarity percentage (SIMPER) for tree species in both areas using the software PAST (Hammer et al., 2001). SIMPER is a nonparametric analysis that identifies how much species contribute to differences within groups (Clark and Warwick, 2001).

\section{Species abundance}

As the interest of this study was to identify possible indicator species of disturbance along the observed gradient, we calculated species abundance per disturbance in each vegetation patch (high, medium and low in shrubland; and high, medium and low in tropical dry forest). We considered especially trees and arborescent shrubs as they are severely affected by anthropogenic factors (Pérez-Negrón and Casas, 2007; Hernández Hernández et al., 2010). As a consequence, differences in species composition and abundance should indicate conservation. Analysis was carried out at the genus level. The genera Acacia Mill. and Mimosa L. were also considered in the analysis because their encroachment capacity has been well documented (Van Auken, 2000). We conducted further analysis using Mexican oregano (Lippia graveolens Kunth), as well as the shrubs Cnidoscolus tehuacanensis Breckon and Mi- mosa luisana Brandegee, in order to determine their possible use as disturbance indicator species.

Shrub frequency was calculated as:

$$
\mathrm{F}=\mathrm{n}_{\mathrm{ij}} / \mathrm{N}_{\mathrm{j}}
$$

where $n_{i j}$ indicates the number of individuals of species $\mathrm{i}$ in patch $\mathrm{j}$, and $\mathrm{Nj}$ represents the total number of individuals recorded in patch $\mathrm{j}$.

Differences between disturbance levels were calculated using an ANOVA (Statistica, 1999). If results were significant, post hoc comparisons were made using a Tukey HSD test.

\section{Results}

\section{Disturbance Index}

Activities recorded for the area ranged from food collection and hunting to mineral extraction activities. On the one hand, some of the activities are considered seasonal, occurring during specific times of the year; these include collection of fruits from different cacti species (Pavón and Briones, 2001), insects (Acuña, 2010), and plants for commerce (Dávila, 2003), as well as hunting. On the other hand, timber extraction occurs throughout the year for cooking and construction as well as grazing and hiking. Patches were classified according to the value obtained from adding the perceived level of the activity in the area (Table 3 ).

\section{Vegetation characterization}

Accumulation curves showed that sampling effort was not sufficient to determine overall plant diversity in Cerro Colorado (Fig. 2). Conversely, when considering the vegetation class "trees", the accumulation curves showed that sampling effort was sufficient to account for tree diversity in the area (Fig. 3). A list of the species that were identified in 60 quadrats can be found in Table 4. Tropical dry forest had more species than shrubland. When considering species richness between "high", "medium", and "low" disturbance areas; the species richness index $(\mathrm{F}=3.50, \mathrm{df}=5,54, \mathrm{p}<0.01)$ and evenness index $(\mathrm{F}=3.50$, $\mathrm{df}=5,54, \mathrm{p}<0.01$ ) showed significant differences (Table 
Table 3: Patch classification according to disturbance level, scores vary according to the perceived disturbance. $1=$ low, $2=$ medium, $3=$ high. Patches were classified according to the score value, with the conserved or low disturbance sites those having scores of less than ten, medium conserved or disturbed sites the ones with scores up to 20 and disturbed sites those with a score of more than 20. CM, SB and AJ indicate patches of tropical dry forest while SD, VA and SAC indicate shrubland patches.

\begin{tabular}{lcccccc}
\hline & CM & SB & AJ & SD & SAC & VA \\
\cline { 2 - 7 } Fruit collection (seasonal) & 1 & 2 & 3 & 1 & 2 & 3 \\
Wood collection for cooking & 1 & 2 & 3 & 1 & 2 & 2 \\
Wood collection for building & 0 & 0 & 0 & 0 & 2 & 0 \\
Hunting & 1 & 1 & 2 & 1 & 1 & 3 \\
Goat browsing & 0 & 0 & 3 & 0 & 1 & 3 \\
Cow browsing & 3 & 1 & 0 & 1 & 0 & 0 \\
Plant collection (seasonal) & 1 & 3 & 3 & 1 & 2 & 2 \\
Hiking & 0 & 0 & 2 & 1 & 1 & 3 \\
Trash in the area & 1 & 2 & 3 & 1 & 2 & 3 \\
Human encounters & 1 & 2 & 3 & 1 & 2 & 3 \\
Total & 9 & 13 & 21 & 8 & 15 & 22 \\
\hline
\end{tabular}

5), while the Shannon index $(\mathrm{F}=2.27, \mathrm{df}=5,54, \mathrm{p}=0.06)$ did not.

Despite similarity in vegetation richness among the vegetation patches, the ANOSIM analysis determined a significant difference between high disturbance and low disturbance areas in both vegetation types (shrubland global $\mathrm{R}=0.546, \mathrm{P}<0.05$; tropical dry forest global $\mathrm{R}=0.78, \mathrm{P}<0.05$ ). The SIMPER analysis of trees in Cerro Colorado identified four genera (out of 16 considered) that explained the top $50 \%$ of the compositional dissimilarity between high and low disturbance areas (Table 6). Of these, three genera (Parkinsonia L., Bursera Jacq. ex L., Thevetia L.) had greater average abundance in low disturbance quadrats and one genus (Ipomoea L.) in the high disturbance quadrats (Fig. 4).

When considering the 46 species present in tropical dry forest, the SIMPER analysis identified eight groups (shrubs, Thevetia peruviana K. Schum., Hechtia podantha Mez, Compositae, Mimosa luisana Brandegee, columnar cacti, Opuntia spp., and Lippia graveolens Kunth) that explain the top $50 \%$ of the compositional dissimilarity between high and low disturbance areas. Five taxa (Mimosa luisana, Columnar cacti, Compositae, Lippia graveolens, and Hechtia podantha) had a higher average abundance in high disturbance areas. In contrast, in low disturbance areas three groups (shrubs, Thevetia peruviana, and Opuntia spp.) presented higher average abundance. When considering trees in tropical dry forest (14 genera), four genera (Thevetia, Acacia, Parkinsona and Bursera) explained all the dissimilarity between high and low disturbance areas. Three of these genera (Thevetia, Acacia and Bursera) had a higher average abundance in low disturbance quadrats (Fig. 5).

When considering the 37 taxa present in shrubland, just four (Agave spp., Hechtia podantha, Opuntia spp., and Lippia graveolens) explained differences between high and low disturbance areas. When considering the class tree within shrubland (11 taxa), only two taxa (Ipomoea and Parkinsonia) explained the top 50\% of the compositional dissimilarity; where just one tree (Parkinsonia) had a higher mean abundance in low disturbance areas (Fig. 6).

\section{Indicator species}

Cerro Colorado had two species that could be used as indicators of places with high and low disturbance levels. The shrubs Mimosa luisana $(\mathrm{F}=5.68, \mathrm{df}=2,56$, $\mathrm{p}<0.05)$ and Cnidoscolus tehuacanensis $(\mathrm{F}=3.19$, $\mathrm{df}=2,56, \mathrm{p}<0.05$ ) presented higher relative abundance in quadrats with high disturbance levels in comparison to those presenting medium and low disturbance levels. As for the tropical dry forest, three genera were significantly different: Acacia $(\mathrm{F}=3.77, \mathrm{df}=2,27, \mathrm{p}<0.05)$; Ceiba Mill. $(\mathrm{F}=12.55, \mathrm{df}=2,27, \mathrm{p}<0.05)$ and Cnidoscolus Pohl $(\mathrm{F}=4.41, \mathrm{df}=2,27, \mathrm{p}<0.05)$, being present in higher densities in low disturbance quadrats. As for shrubland, medium disturbance quadrats had three taxa that are significantly more abundant than in other quadrats: the tree Tecoma stans (L.) Juss. ex Kunth $(\mathrm{F}=3.38, \mathrm{df}=2,26$, $\mathrm{p}<0.05)$, the shrub Mimosa luisana $(\mathrm{F}=5.16, \mathrm{df}=2,26$, $\mathrm{p}<0.05)$, and the genus Acacia $(\mathrm{F}=3.77, \mathrm{df}=2,26$, 


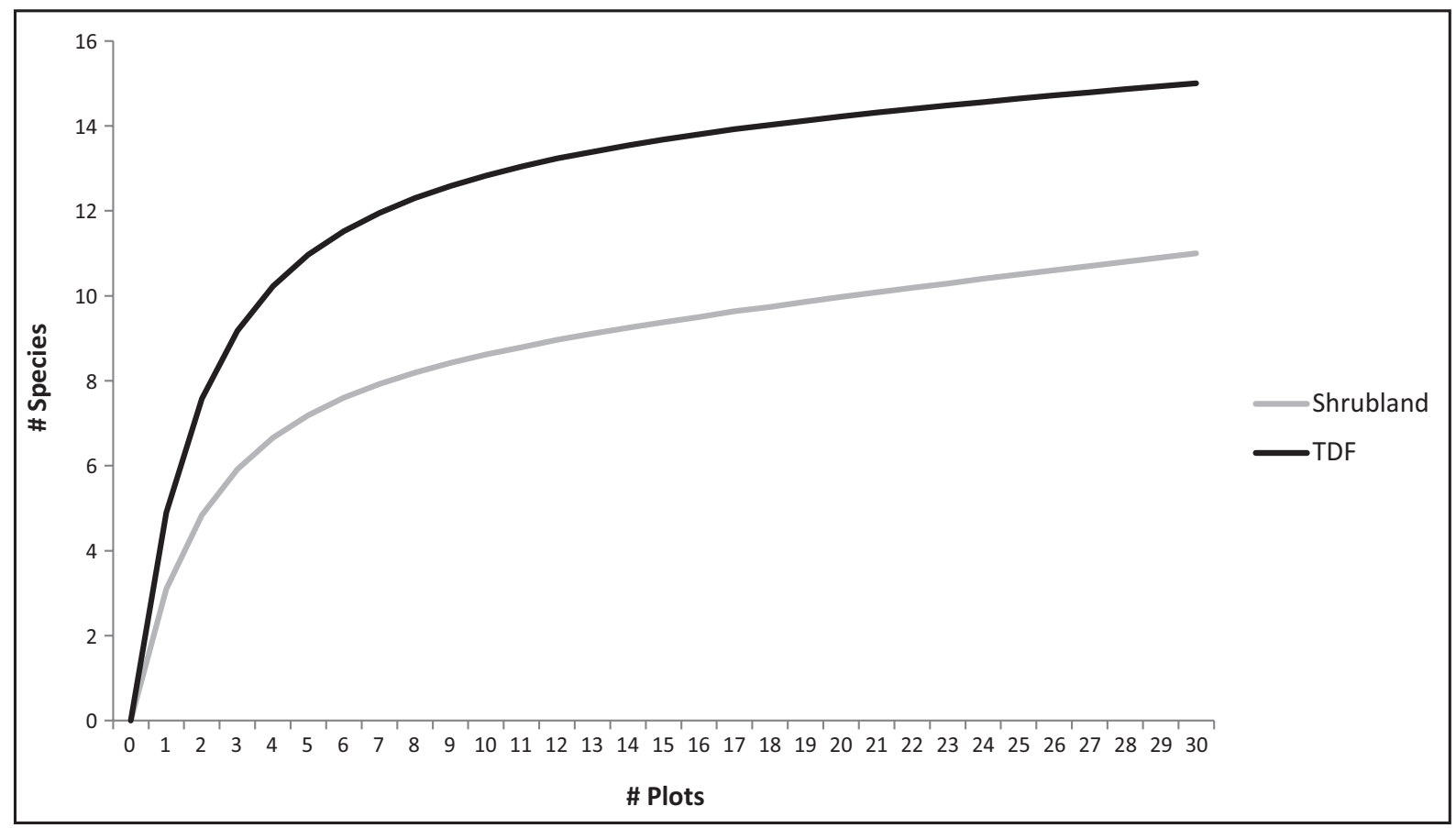

Figure 2: Species accumulation curves using Mau Tau (Colwell, 2006) for shrubland and tropical dry forest (TDF) in Cerro Colorado. Data corresponds to 30 quadrats sampled on each vegetation type.

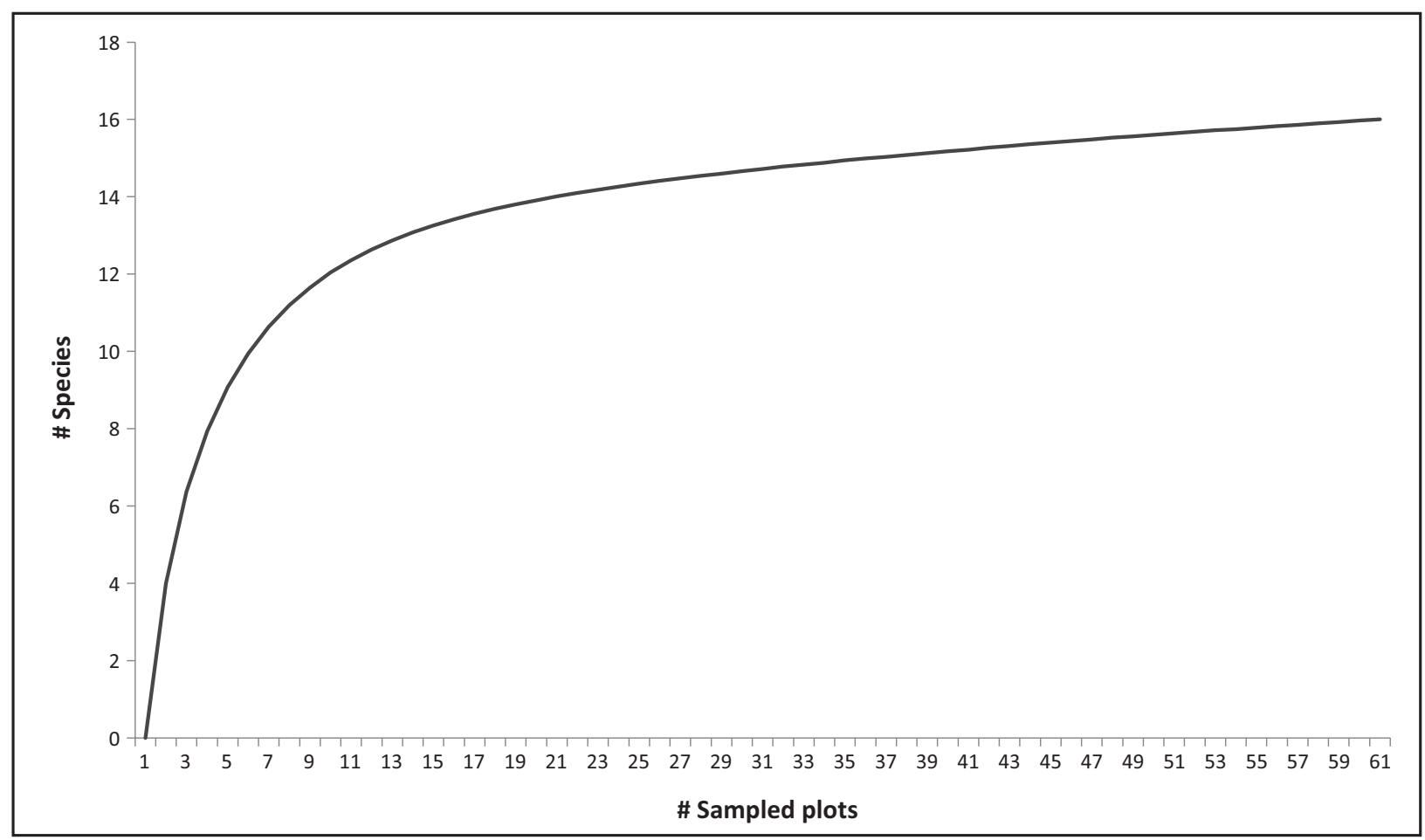

Figure 3: Species accumulation curve using Mau Tau (Colwell, 2006) for Cerro Colorado considering all the species found in the 60 vegetation quadrats. 
Table 4: List of principal species that were found in 60 quadrats surveyed in the six study sites in Cerro Colorado, grouped according to vegetation type. Identification was carried out with Guízar Nolazco and Sánchez Velez (1991); Aguilar Santelises and García (2004); Téllez Valdés et al. (2008) and Huerta Zamacona et al. (2009).

\begin{tabular}{|c|c|}
\hline Shrubland & Tropical dry forest \\
\hline Acacia constricta Benth. & Acacia bilimekii J.F. Macbr. \\
\hline Acacia cochliacantha Humb. \& Bonpl. ex Willd. & Acacia constricta Benth. \\
\hline Acacia sp. & Acacia subangulata Rose \\
\hline Agave sp. & Acacia cochliacantha Humb. \& Bonpl. ex Willd. \\
\hline Agave horrida Lem. ex Jacobi & Agave spp. \\
\hline Agave marmorata Roezl. & Beaucarnea gracilis Lem. \\
\hline Bursera aloexylon (Schiede ex Schlecht.) Engl. & Bursera aloexylon (Schiede ex Schltdl.) Engl. \\
\hline Bursera copallifera (DC.) Bullock & Bursera aptera Ramírez \\
\hline Bursera longipes (Rose) Standl. & Bursera bipinnata (Sessé \& Moc. ex DC.) Engl. \\
\hline Bursera sp. & Bursera fagaroides (Kunth) Engl. \\
\hline Bursera aptera Ramírez & Bursera glabrifolia (Kunth) Engl. \\
\hline Bursera fagaroides (Kunth) Engl. & Bursera submoniliformis Engl. \\
\hline Castela erecta Turp. & Bursera copallifera (DC.) Bullock \\
\hline Ceiba parviflora Rose & Castela erecta Turp. \\
\hline Cnidoscolus tehuacanensis Breckon & Ceiba parviflora Rose \\
\hline Dodonaea viscosa (L.) Jacq. & Cnidoscolus tehuacanensis Breckon \\
\hline Echinocactus platyacanthus Link \& Otto & Cyrtocarpa procera Kunth \\
\hline Fouquieria formosa Kunth & Ephedra compacta Rose \\
\hline Hechtia podantha $\mathrm{Mez}$ & Eupatorium spp. \\
\hline Ipomoea murucoides Roem. \& Schult. & Euphorbia antisiphyllitica Zucc. \\
\hline Lippia graveolens Kunth & Euphorbia spp. \\
\hline Lysiloma microphyllum Benth. & Fouquieria formosa Kunth \\
\hline Marrubium vulgare L. & Hechtia podantha $\mathrm{Mez}$ \\
\hline Mimosa luisana Brandegee & Ipomoea murucoides Roem. \& Schult. \\
\hline Mimosa aculeaticarpa Ort. & Jatropha neopauciflora $\mathrm{Pax}$ \\
\hline Myrtillocactus geometrizans (Mart.) DC. & Lippia graveolens Kunth \\
\hline Opuntia decumbens Salm-Dyck & Lysiloma microphylla Benth. \\
\hline Opuntia pilifera Weber & Marrubium vulgare L. \\
\hline Parkinsonia praecox (Ruiz \& Pav. ex Hook) Hawkins & Mimosa aculeaticarpa Ort. \\
\hline Prosopis laevigata (Humb. \& Bonpl. ex Willd.) M.C. Johnst. & Mimosa luisana Brandegee \\
\hline Sedum sp. & Myrtillocactus geometrizans (Mart.) DC. \\
\hline Senecio sp. & Opuntia pilifera Weber \\
\hline Stevia lucida Lag. & Parkinsonia praecox (Ruiz \& Pav.) \\
\hline Tecoma stans (L.) Juss. ex Kunth & Pithecellobium dulce (Roxb.) Benth. \\
\hline Yucca periculosa Baker & Plumeria rubra L. \\
\hline \multirow[t]{3}{*}{ Ziziphus amole (Sessé \& Moc.) M.C. Johnst. } & Prosopis laevigata (Humb. \& Bonpl. ex Willd.) M.C. Johnst. \\
\hline & Sedum spp. \\
\hline & Senecio spp. \\
\hline
\end{tabular}


Table 4: Continuation.

\begin{tabular}{ll}
\hline Shrubland & Tropical dry forest \\
\hline & Stevia lucida Lag. \\
& Tecoma stans (L.) Juss. ex Kunth \\
Thevetia peruviana (Pers.) K. Schum. & Yucca periculosa Baker \\
& Ziziphus amole (Sessé \& Moc.) M.C. Johnst. \\
\hline
\end{tabular}

Table 5: Comparison of vegetation quadrats made in each patch: Shannon index, species richness and species evenness given as average with standard deviation. Below, the ANOVA statistics, species richness and evenness are significant, with a difference among VA and CM.

\begin{tabular}{llccc}
\hline Disturbance & $\mathrm{N}$ & Shannon Index \pm SD & Species richness \pm SD & Species Evenness \pm SD \\
\hline AJ & 10 & $0.87 \pm 0.04$ & $0.86 \pm 0.03$ & $0.14 \pm 0.03$ \\
CM & 10 & $0.86 \pm 0.05$ & $0.88 \pm 0.04$ & $0.12 \pm 0.04$ \\
SAC & 10 & $0.82 \pm 13$ & $0.77 \pm 0.17$ & $0.23 \pm 0.17$ \\
SB & 10 & $0.83 \pm 0.07$ & $0.84 \pm 0.07$ & $0.16 \pm 0.07$ \\
SD & 10 & $0.80 \pm 0.10$ & $0.77 \pm 07$ & $0.23 \pm 0.07$ \\
VA & 10 & $0.74 \pm 0.13$ & $0.75 \pm 0.11$ & $0.25 \pm 0.11$ \\
\hline
\end{tabular}

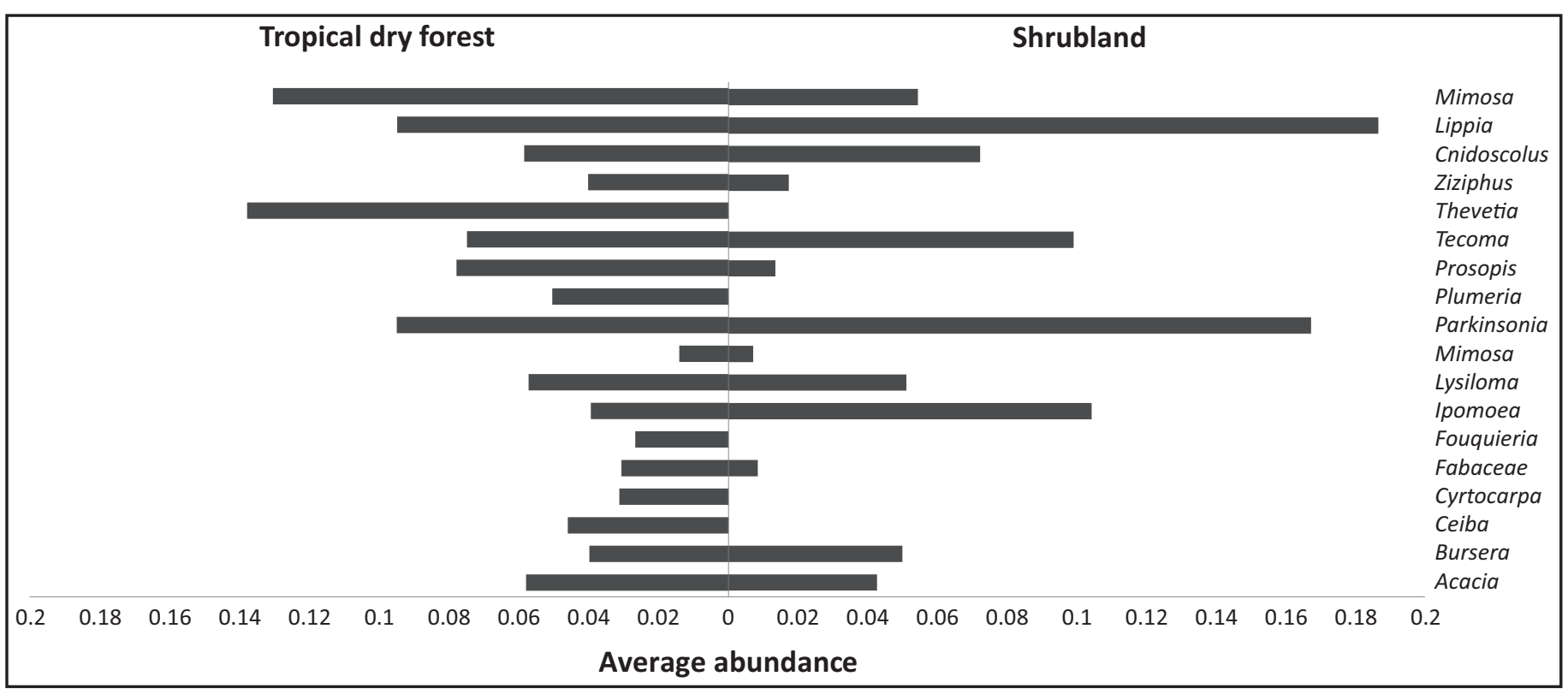

Figure 4: Abundance of tree genera (bars) in shrubland vs. tropical dry forest in Cerro Colorado. The graph shows those genera that accounted for $50 \%$ of dissimilarity in genus composition between vegetation types, as identified by SIMPER analysis. 
Table 6: Species contributing to the top 50\% of dissimilarity in species composition between the high and low disturbance areas in tropical dry forest and shrubland, and Cerro Colorado ordered by proportional contribution. The table indicates results using all morphospecies and just tree genera. Contribution and cumulative values are given in \%. For Cerro Colorado, results indicate just tree genera.

\begin{tabular}{|c|c|c|c|c|c|c|}
\hline \multirow[t]{2}{*}{ Vegetation } & \multirow[t]{2}{*}{ Species } & \multirow[t]{2}{*}{ Taxon/Group } & \multicolumn{2}{|c|}{ Disturbance } & \multirow[t]{2}{*}{ Contribution } & \multirow[t]{2}{*}{ Cumulative $\%$} \\
\hline & & & High & Low & & \\
\hline \multirow{13}{*}{$\begin{array}{l}\text { Tropical dry } \\
\text { forest }\end{array}$} & \multirow[t]{13}{*}{ All } & Shrubs & 0.66 & 8.1 & 6.49 & 8.33 \\
\hline & & Thevetia peruviana & 0 & 7.4 & 6.16 & 16.26 \\
\hline & & Hechtia podantha & 7 & 2.7 & 6.05 & 24.03 \\
\hline & & Mimosa luisana & 7.33 & 1 & 5.71 & 31.37 \\
\hline & & Columnar cacti & 8.33 & 4.5 & 4.63 & 37.32 \\
\hline & & Opuntia spp. & 3.56 & 4.9 & 4.55 & 43.17 \\
\hline & & Compositae & 6.22 & 2.8 & 4.42 & 48.86 \\
\hline & & Lippia graveolens & 4.89 & 0.5 & 3.94 & 53.92 \\
\hline & & & High & Low & Contribution & Cumulative \% \\
\hline & & Thevetia & 0 & 7.4 & 16.5 & 20.39 \\
\hline & & Acacia & 1 & 4.5 & 10.15 & 32.93 \\
\hline & & Parkinsonia & 4.9 & 2 & 10.11 & 45.42 \\
\hline & & Bursera & 2 & 4.6 & 9.81 & 57.55 \\
\hline \multirow{8}{*}{ Shrubland } & \multirow{5}{*}{ All } & & High & Low & Contribution & Cumulative $\%$ \\
\hline & & Agave spp. & 25.2 & 2.9 & 12.52 & 16.52 \\
\hline & & Hechtia podantha & 10 & 21 & 12.49 & 32.99 \\
\hline & & Opuntia spp. & 13.5 & 2.4 & 7.25 & 42.56 \\
\hline & & Lippia graveolens & 11.7 & 13 & 5.91 & 50.37 \\
\hline & \multirow[t]{3}{*}{ Trees } & & High & Low & Contribution & Cumulative $\%$ \\
\hline & & Ipomoea & 5.6 & 5.6 & 21.08 & 26.91 \\
\hline & & Parkinsonia & 0 & 6.3 & 20.25 & 52.76 \\
\hline \multirow{5}{*}{ Cerro Colorado } & \multirow{5}{*}{ Trees } & & High & Low & Contribution & Cumulative \% \\
\hline & & Parkinsonia & 2.45 & 4.15 & 13.73 & 17.69 \\
\hline & & Ipomoea & 4 & 3.25 & 13.57 & 35.18 \\
\hline & & Bursera & 2.15 & 3.6 & 10.52 & 48.74 \\
\hline & & Thevetia & 0 & 3.7 & 8.3 & 59.43 \\
\hline
\end{tabular}

$\mathrm{p}<0.05$ ). On the other hand, Mexican oregano (Lippia graveolens $)(\mathrm{F}=4.08, \mathrm{df}=2,26, \mathrm{p}<0.05)$ was less abundant in medium disturbed patches. Finally, the shrub Cnidoscolus tehuacanensis $(\mathrm{F}=5.72, \mathrm{df}=2,26, \mathrm{p}<0.05$ ) was present in higher numbers in high disturbance quadrats.

\section{DISCUSSION}

Our results show that tropical dry forest in the area is more diverse than shrubland (40 vs. 26 taxa).
Conversely, other studies based on a regional scale have found that shrubland is more diverse than tropical dry forest (Valiente-Banuet et al., 2000). We suggest these differences could be due to higher alpha diversity (site richness) in tropical dry forest at local level but higher beta diversity (richness in all patches) in shrubland at regional level. Furthermore, high species richness in semi-arid environments have been linked with species facilitation processes (Espinosa et al., 2011). However, in our area it seems to be more related with higher humidity 


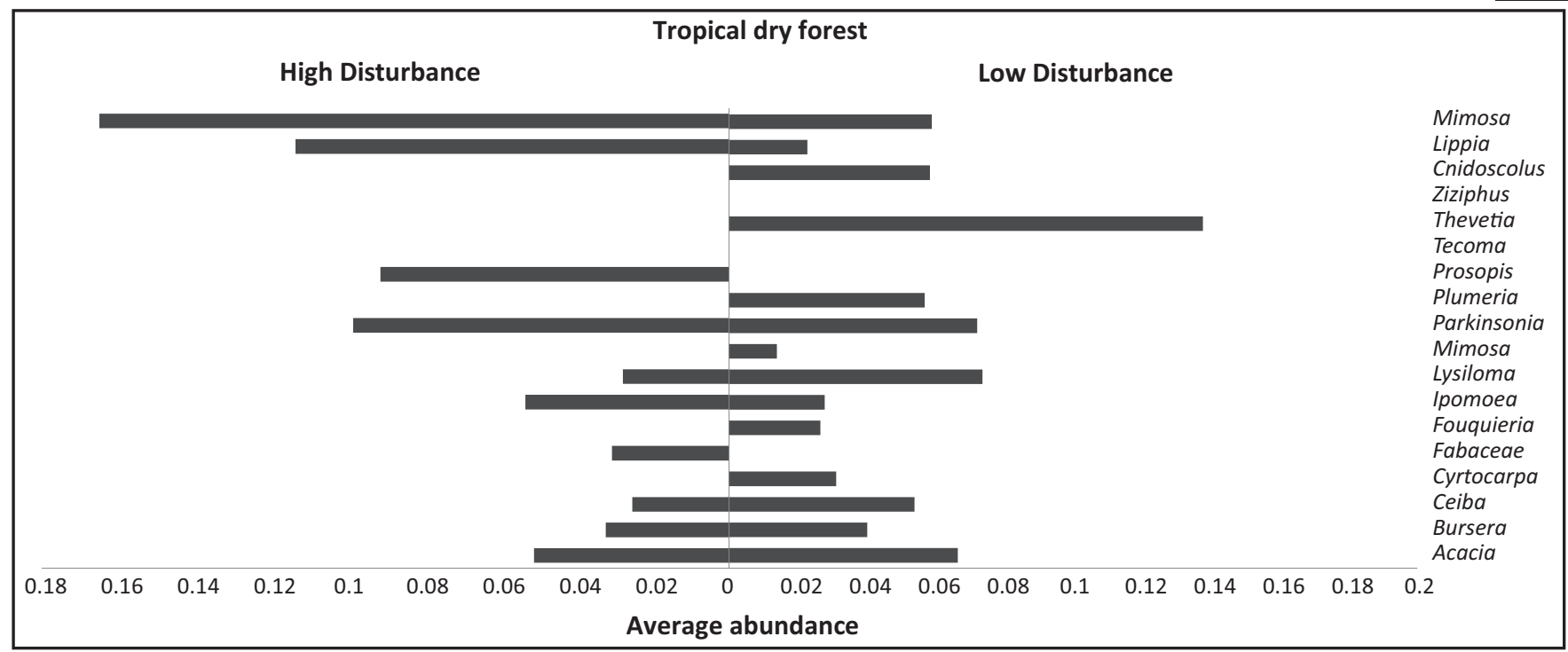

Figure 5: Abundance of tree genera in high disturbance vs. low disturbance in tropical dry forest in Cerro Colorado. The graph shows those genera that accounted for $50 \%$ of dissimilarity in genus composition between disturbance types, as identified by SIMPER analysis.

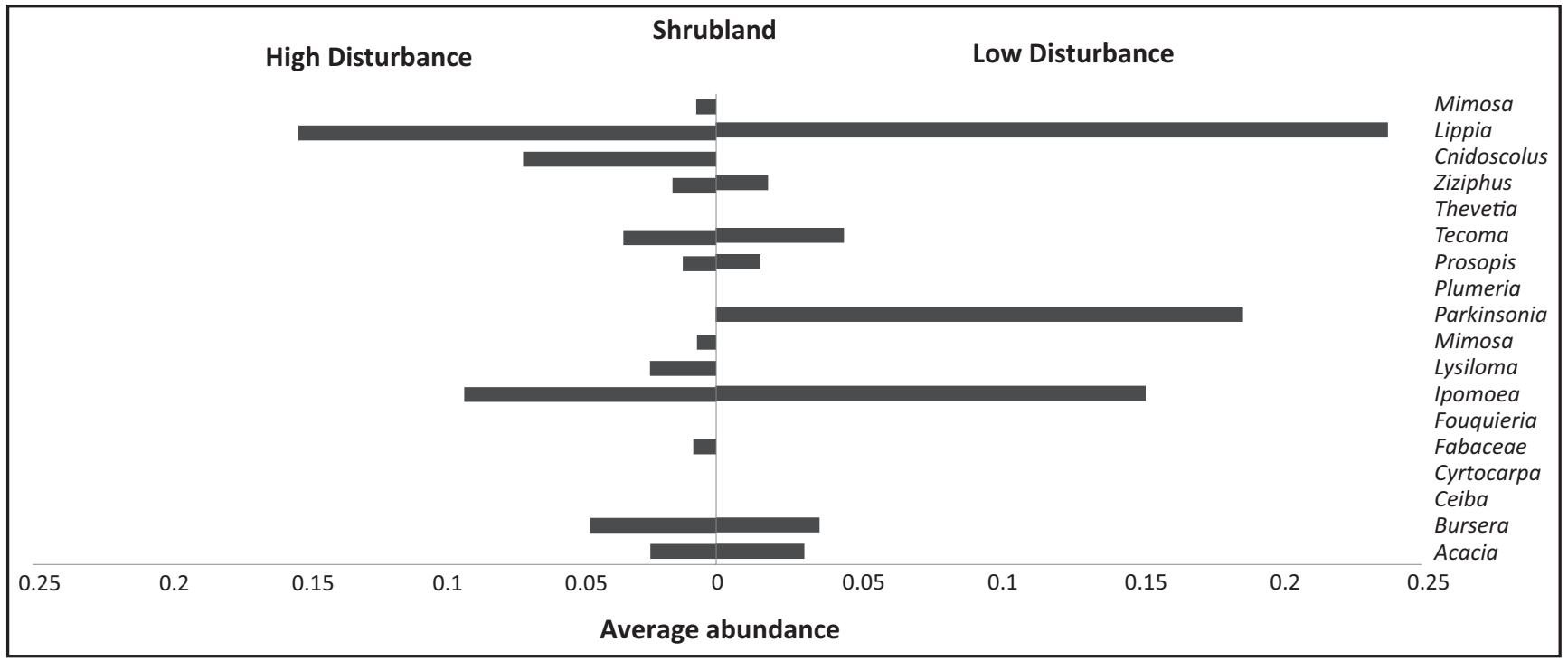

Figure 6: Abundance of tree genera in high disturbance vs. low disturbance in shrubland in Cerro Colorado. The graph shows those genera that accounted for $50 \%$ of dissimilarity in genus composition between disturbance types, as identified by SIMPER analysis.

levels and more microhabitats for plants (Murphy and Lugo, 1986). This has been documented for other taxa in the region such as mycorrhizal species (Camargo-Ricalde and Esperón-Rodríguez, 2005), and carnivores (Ramírez Pulido and Martínez Vázquez, 2007).
Our results show that there are significant differences between the quadrats surveyed when considering richness and evenness, but not for the Shannon index. The Tukey test revealed only a difference between CM and VA (Table 3). The latter could be due to insufficient sampling effort, despite 
the fact we covered the recommended area (10\%) to identify plant diversity (Sánchez-Lalinde and Pérez-Torres, 2008).

The disturbance index proved useful for determining disturbance level among the different sampling areas in a simplistic manner. This study assumed that an additive approach to assessing the impact of different disturbances would be appropriate. However, it is necessary to generate an index considering the relationships and intensity of each variable with disturbance levels as they have a varied influence when generating changes in species diversity and composition. Furthermore, it has been recorded how some disturbances can have a long term effect over the environment changing original plant species composition and abundance (Espinosa et al., 2011; Ross, 2011) and in some cases favoring plant establishment (Hawkes and Flechtner, 2002; Ross, 2011). Examples include goat grazing and wood extraction, both of which have a stronger effect over habitat composition than other factors such as littering or hiking due to their capacity to alter plant communities over long periods of time as has been documented in other habitats in North America (Ripple and Beschta, 2008). Additionally, several plants that act as nurse plants (Castillo Landero and Valiente-Banuet, 2010) or create resource islands (Camargo-Ricalde et al. 2002) in the region are heavily exploited (Pérez-Negrón and Casas, 2007), which can promote long-term effects over species compositions.

In the case of the Tehuacán-Cuicatlán Valley, species of the genera Mimosa and Prosopis L. have been documented to create resource islands (Camargo-Ricalde et al., 2003) and to function as nurse plants (Castillo-Landero and Valiente-Banuet, 2010). However, they are heavily consumed by goats, which are also considered as good dispersers for both species (for Prosopis, Baraza and Valiente-Banuet, 2008, and for Mimosa, Giordani, 2008). This in turn promotes that disturbed environments especially by grazing increase densities of both genera resulting in an increase in shrub density.

Our results indicate that it is possible to select some species as indicators of disturbance due to a difference in their presence along the landscape. For instance, some genera that are used for wood extraction have a higher abundance in low disturbance areas in tropical dry forest (Thevetia, Ceiba, Acacia and Parkinsonia) and low disturbance in shrubland (Parkinsonia) (Paredes-Flores et al., 2007) compared to quadrats with high disturbance levels. With high disturbance, exploited species have changed their abundance (Willis et al., 2003). On the other hand, we found that two shrubs, Cnidoscolus tehuacanensis and Mimosa luisana, occurred in high numbers in disturbed quadrats in Cerro Colorado. In other areas, Mimosa luisana and other species from the same genera are known to be prone to encroachment (Legesse, 2010). The shrub Cnidoscolus tehuacanensis reacted different when data were analyzed by vegetation patch. In tropical dry forest C. tehuacanensis was more abundant in low disturbance areas, while in shrubland it was found more abundant in high disturbance levels. Hence, our results suggest that both species could be appropriate as disturbance indicator species in the area while for low disturbance levels, the genera Thevetia, Ceiba and Bursera could be used in tropical dry forest and Parkinsonia in shrubland. However, further sampling is necessary to determine the effectiveness of each genus.

\section{Implications for conservation}

This study shows the responses of two vegetation types present in the region along a disturbance gradient with varied activities that go from fruit collection to agricultural practices. The disturbance index used herein could be useful for community management and quick assessments in the area when they need an assessment for activities such as tourism as the index is easy to apply and calculate. It is proposed that goat grazing and fruit collection can have more long term impact over the species composition as previously thought; hence, conservation plans undertaken in the area need to integrate human activities to ensure long term functionality.

\section{LITERATURE CITED}

Acuña Cors, A. M. 2010. Etnoecología de insectos comestibles y su manejo tradicional por la comunidad indígena de los 
Reyes Metzontla, municipio de Zapotitlán Salinas, Puebla. Tesis de maestría. Colegio de Postgraduados Campus Puebla. Puebla, Mexico. 199 pp.

Aguilar Santelises, R. and R. García. 2004. Catálogo de plantas reportadas como parte de la dieta de la guacamaya verde (Ara militaris) en la región de la cañada Oaxaqueña. Instituto Politécnico Nacional, Centro Interdisciplinario de Investigación para el Desarrollo Integral Regional, Unidad Oaxaca. Oaxaca, Mexico. 44 pp.

Baraza, E. and A. Valiente-Banuet. 2008. Seed dispersal by domestic goats in a semiarid thorn scrub of Mexico. Journal of Arid Environments 72(10): 1973-1976. DOI: http://dx. doi.org/10.1016/j.jaridenv.2008.04.004

Blaum, N., E. Rossmanith, A. Popp and F. Jeltsch. 2007. Shrub encroachment affects mammalian carnivore abundance and species richness in semiarid rangelands. Acta Oecologica 31(7): 86-92. DOI: http://dx.doi.org/10.1016/j. actao.2006.10.004

Bolaños-Bautista, E. 2011. Mapa de la clasificación supervisada de la vegetación, Cerro Colorado-La Hierbabuena. Centro Regional de Enseñanza de Ciencia y Tecnología del Espacio para América Latina y el Caribe-México. Tonanzintla, Puebla, Mexico.

Botello, F., J. M. Salazar, P. Illoldi-Rangel, M. Linaje, G. Monroy and D. Duque. 2006. Primer registro de la nutria neotropical de río (Lontra longicaudis) en la Reserva de la Biosfera de Tehuacán-Cuicatlán, Oaxaca, Mexico. Revista Mexicana de Biodiversidad 77: 133-135.

Camargo-Ricalde, S. L. and M. Esperón-Rodríguez. 2005. Efecto de la heterogeneidad espacial y estacional del suelo sobre la abundancia de hongos micorrizógenos arbusculares en el valle semi-árido de Tehuacán-Cuicatlán, México. Revista de Biología Tropical 53(3-4): 339-352.

Camargo-Ricalde, S. L., S. S. Dhillion and C. JiménezGonzález. 2003. Mycorrhizal perennials of the "matorral xerófilo" and the "bosque tropical caducifolio" communities in the semiarid Tehuacán-Cuicatlán Valley, Mexico. Mycorrhiza 13: 77-83. DOI: http://dx.doi.org/10.1007/ s00572-002-0203-8

Camargo-Ricalde, S. L., S. S. Dhillion and R. Grether. 2002. Community structure of endemic Mimosa species and en- vironmental heterogeneity in a semi-arid Mexican valley. Journal of Vegetation Science 13(2): 697-704.

Castillo Landero, J. P. and A. Valiente-Banuet. 2010. Species-specificity of nurse plants for the establishment, survivorship, and growth of a columnar cactus. American Journal of Botany 97(8): 1289-95. DOI: http://dx.doi. org/10.3732/ajb.1000088

Clark, K. R. and R. M. Warwick. 2001. Change in marine communities: An approach to statistical analysis and interpretation. 2nd edition. PRIMER-E. Plymouth, UK. $172 \mathrm{pp}$.

Collinge, S. K., K. L. Prudic and J. C. Oliver. 2003. Effects of local habitat characteristics and landscape context on grassland butterfly diversity. Conservation Biology 17(1): 178-187.

Colwell, R. K. 2006. Estimate S: Statistical estimation of species richness and shard species for samples, Version 8, Available from: http://purl.oclc.org/estimates

Crooks, K. R. 2002. Relative sensitivities of mammalian carnivores to habitat fragmentation. Conservation Biology 16(2): 488-502.

Dávila, P. 2003. La flora útil de dos comunidades indígenas del Valle Tehuacán-Cuicatlán: Coxcatlán y Zapotitlán de las Salinas, Puebla, México. Proyecto No. T015. Informe final Sistema Nacional de Información sobre Biodiversidad-Comisión Nacional para el Uso y Conocimiento de la Biodiversidad. Puebla, México. 73 pp.

Espinosa, C. I., O. Cabrera, A. L. Luzuriaga and A. Escudero. 2011. What factors affect diversity and species composition of endangered tumbesian dry forests in southern Ecuador? Biotropica 43(1): 15-22. DOI: http://dx.doi. org/10.1111/j.1744-7429.2010.00665.x

Giordani, L. 2008. The role of goats in germination and dispersal of Mimosa luisana Brandegee (Leguminosae-Mimosoideae) seeds in Tehuacán-Cuicatlán Valley, Puebla State, Mexico. Master Thesis. Department of International Environment and Development Studies. Norwegian University of Life Sciences. Oslo, Norway. 32pp.

González-Soberanes, C. and A. Casas. 2004. Traditional management and domestication of tempesquistle, Sideroxylon palmeri (Sapotaceae) in the Tehuacán-Cuicat- 
lán Valley, Central Mexico. Journal of Arid Environments 59(2): 245-258. DOI: http://dx.doi.org/10.1016/j. jaridenv.2004.01.018

Guízar Nolazco, E. and A. Sánchez Velez. 1991. Guía para el reconocimiento de los principales árboles del Alto Balsas. Mexico: Dirección de Difusión Cultural, División de Ciencias Forestales, Universidad Autónoma Chapingo. México, D.F., Mexico. 207 pp.

Hammer, Ø., D. A. T. Harper and P. D. Ryan. 2001. PAST: Paleontological statistics software package for education and data analysis. Palaeontología Electrónica 4(1): 1-9.

Hawkes, C. V. and V. R. Flechtner. 2002. Biological soil crusts in a xeric Florida shrubland: composition, abundance, and spatial heterogeneity of crusts with different disturbance histories. Microbial Ecology 43(1): 1-12. DOI: http://dx. doi.org/10.1007/s00248-001-1017-5

Hernández Hernández, J. E., J. C. Camacho Ronquillo, O. A. Villarreal Espino-Barros, F. J. Franco Guerra, L. M. Aguilar Guzmán and M. G. E. Sorcia Cid. 2010. Plantas leñosas y partes preferidas que consumen las cabras de la Mixteca Poblana, México. Memorias del XXXV Congreso de la Sociedad Española de Ovinotecnia y Caprinotecnia. Valladolid, España. pp. 255-259.

Huerta Zamacona, S., A. Vidal Corona, J. Rodríguez Rodríguez, M. Bonilla Vichot, M. Mora Pérez, S. Vázquez Martínez, G. A. Ortiz Rivera and F. Bravo Hernández. 2009. Principales árboles y arbustos en el bosque tropical caducifolio de la mixteca baja poblana, Puebla, Mexico. Instituto Tecnológico de Tecomatlán, Fundación Produce, A.C. Instituto de Investigaciones Forestales. México. 118 pp.

Legesse, Y. 2010. Assessment of the distribution and spread of invasive alien plant species with major emphasis on Mimosa invisa Mart. ex Colla in the high lands of Ethiopia: the case of south western zones of Oromia and SNNPRS. Master Thesis. College of Natural Science, Addis Ababa University. Addis Ababa, Ethiopia. 106 pp.

McDougall, A. S. and R. Turkington. 2005. Are invasive species the drivers or passengers of change in degraded ecosystems? Ecology 86(1): 42-55. DOI: http://dx.doi. org/10.1890/04-0669

Moreno, C. E. 2001. Métodos para medir la biodiversidad. Vol.
1. Manuales y Tesis de la Sociedad Entomológica Aragonesa. Zaragoza, España. 54 pp.

Murphy, P. G. and A. E. Lugo. 1986. Ecology of tropical dry forest. Annual Review of Ecology and Systematics 17: 67-88.

Myers, N. 1988. Threatened biotas: 'hotspots' in tropical forests. Environmentalist 8: 187-208.

Nikiema, A. 2005. Agroforestry parkland species diversity: uses and management in semi-arid West Africa (Burkina Faso). PhD. Dissertation. Wageningen University. Wageningen, The Netherlands. $112 \mathrm{pp}$.

Oksanen, J., F. G. Blanchet, R. Kindt, P. Legendre, P. R. Minchin, R. B. O'Hara, G. L. Simpson, P. Solymos, M. Henry, H. Stevens and H. Wagner. 2011. Vegan: Community Ecology Package. R package version 2.0-2. http:// CRAN.R-project.org/package= $=$ vegan

Osem, Y., A. Perevolotsky and J. Kigel. 2002. Grazing effect on diversity of annual plant communities in a semi-arid rangeland: interactions with small-scale spatial and temporal variation in primary productivity. Journal of Ecology 90(6): 936-946. DOI: http://dx.doi.org/10.1046/ j.1365-2745.2002.00730.x

Palomares, F. 2001. Vegetation structure and prey abundance requirements of the Iberian lynx: Implications for the design of reserves and corridors. Journal of Applied Ecology 38: 9-18.

Paredes-Flores, M., S. Lira and P. D. Dávila Aranda. 2007. Estudio etnobotánico de Zapotitlán Salinas, Puebla. Acta Botanica Mexicana 79: 13-61.

Parra, F., N. Pérez-Nasser, R. Lira, D. Pérez-Salicrup and A. Casas. 2008. Population genetics and process of domestication of Stenocereus pruinosus (Cactaceae) in the Tehuacán Valley, México. Journal of Arid Environments 72(11): 1997-2010. DOI: http://dx.doi.org/10.1016/j. jaridenv.2008.06.007

Pavón, P. N. and O. Briones. 2001. Phenological patterns of nine perennial plants in an intertropical semi-arid Mexican scrub. Journal of Arid Environments 49: 265-277.

Pérez-Negrón, E. and A. Casas. 2007. Use, extraction rates and spatial availability of plant resources in the Tehuacán-Cuicatlán Valley, Mexico: The case of Santiago Quiotepec, 
Oaxaca. Journal of Arid Environments 70(2): 356-379.

DOI: http://dx.doi.org/10.1016/j.jaridenv.2006.12.016

Ramírez Pulido, J. and J. Martínez Vázquez. 2007. Diversidad de los mamíferos de la Reserva de la Biósfera TehuacánCuicatlán, Puebla-Oaxaca, México. Proyecto No. BK022. Informe final Sistema Nacional de Información sobre Biodiversidad-Comisión Nacional para el Uso y Conocimiento de la Biodiversidad. Puebla, México. 16 pp.

Ramírez-Bravo, O. E. 2010. Reporte del jaguar en Puebla: presencia, distribución, relación con el hombre y conservación. Reporte para el segundo año, 2009-2010. Grupo Interdisciplinario por la Conservación de Recursos Naturales y Biodiversidad A.C (CREANATURA). Puebla, Mexico. 68 pp.

Ripple, W. J. and R. L. Beschta. 2008. Trophic cascades involving cougar, mule deer, and black oaks, in Yosemite National Park. Biological Conservation 141: 1249-1256.

Ross, N. J. 2011. Modern tree species composition reflects ancient Maya "forest gardens" in northwest Belize. Ecological Applications 21(1): 75-84. Retrieved from http:// www.ncbi.nlm.nih.gov/pubmed/21516889

Sánchez-Lalinde, C. and J. Pérez-Torres. 2008. Uso de hábitat de carnívoros simpátricos en una zona de bosque seco tropical de Colombia. Mastozoología Neotropical 15(1): 67-74.

SEMARNAP. 2001. Inventario Nacional Forestal 2000-2001. Escala 1: 250,000. Secretaría del Medio Ambiente, Recursos Naturales y Pesca - Instituto Nacional de Estadística, Geografía e Informática y Dirección General de Geografía-Universidad Nacional Autónoma de México. México, D.F., Mexico.

SSC. 2012. Statistical Services Center. Diversity Add-In for Microsoft ${ }^{\circledR}$ Excel $^{\mathrm{TM}}$, University of Reading. Reading, UK. http://www.reading.ac.uk/ssc/n/software/diversity/ Diversity.html

Statistica. 1999. StatSoft, Inc. STATISTICA for Windows (Computer program manual). StatSoft, Inc. Tulsa, USA. http://www.statsoft.com

Taki, H., B. F. Viana, P. G. Kevan, F. O. Silva and M. Buck. 2007. Does forest loss affect the communities of trap-nesting wasps (Hymenoptera: Aculeata) in forests? Landscape vs. local habitat conditions. Journal of Insect Conservation 12(1): 15-21. DOI: http://dx.doi.org/10.1007/s10841006-9058-1

Téllez Valdés, O., M. Reyes Castillo, P. Dávila Aranda, K. Gutiérrez García, O. Téllez Poo, R. Álvarez Espino, A. González Romero, I. Rosas Ruíz, M. Ayala Razo, M. Hernández Moreno, M. Murguía Romero, U. Guzmán Cruz. 2008. Guía ecoturística de las plantas del Valle de Tehuacán-Cuicatlán. VolksWagen, Universidad Nacional Autónoma de México, Millenium Seed Bank Project KEW. Puebla, México. 54 pp.

Valéry, L., V. Bouchard and J. C. Lefeuvre. 2004. Impact of the invasive native species Elymus athericus on carbon pools in a salt marsh. Wetlands 24: 268-276.

Valiente-Banuet, A., A. Casas, A. Alcántara, P. Dávila, N. Flores-Hernández, M. C. Arizmendi, J. L. Villaseñor and J. Ortega Ramírez. 2000. La vegetación del Valle de Tehuacán-Cuicatlán. Boletín de la Sociedad Botánica de México 67: 24-74.

Van Auken, O. W. 2000. Shrub invasions of North American semiarid grasslands. Annual Review of Ecology and Systematics 31: 197-215.

Vieira, D. L. M. and A. Scariot. 2006. Principles of natural regeneration of tropical dry forests for restoration. Restoration Ecology 14(1): 11-20. DOI: http://dx.doi. org/10.1111/j.1526-100X.2006.00100.x

Wezel, A. and T. Rath. 2002. Resource conservation strategies in agro-ecosystems of semi-arid West Africa. The Journal of Arid Environments 51(3): 383-400. DOI: http://dx.doi. org/10.1006/jare.2001.0968

Willis, T. J., R. B. Millar and R. C. Babcock. 2003. Protection of exploited fish in temperate regions: high density and biomass of snapper Pagrus auratus (Sparidae) in northern New Zealand marine reserves. Journal of Applied Ecology 40(2): 214-227. DOI: http://dx.doi.org/10.1046/ j.1365-2664.2003.00775.x 